\title{
Penerapan Model Pembelajaran Tandur dalam Meningkatkan Hasil Belajar IPS pada Siswa Kelas V SD Inpress Bontoloe Kecamatan Kabupaten Gowa
}

\author{
Abrina Maulidnawati Jumrah \\ Universitas Islam Makassar \\ * Corresponding Author. E-mail: abrinairwan@gmail.com.
}

\begin{abstract}
Abstrak
Penelitian ini mengkaji tentang Peningkatan hasil belajar IPS melalui penerapan model pembelajaran TANDUR pada siswa kelas V SD Inpres Bontoloe Kecamatan Bontolempangan Kabupaten Gowa. Inpres Daya 1 Kecamatan Biringkanaya Kota Makassar. Tujuan penelitian ini yaitu (1) Bagaimanakah penerapan model pembelajaran TANDUR di Kelas V SD Inpres Bontoloe Kecamatan Bontolempangan Kabupaten Gowa?(2) Bagaimanakah hasil belajar IPS siswa Kelas V SD Inpres Bontoloe Kecamatan Bontolempangan Kabupaten Gowa setelah menerapkan model pembelajaran TANDUR? Penelitian ini merupakan penelitian Tindakan Kelas (PTK) yang dilaksanakan dalam dua siklus. Tiap siklus terdiri dari empat tahap, yakni 1) Perencanaan; 2) pelaksanaan tindakan; 3) observasi: dan 4) refleksi. Subyek penelitian adalah guru dan siswa kelas V SD Inpres Bontoloe yang berjulmalah 28 orang. Penelitian ini dilaksanakan pada semester ganjil tahun pelajaran 2020/2021. Instrumen yang digunakan dalam penelitian ini adalah lembar observasi guru dan siswa, tes hasil belajar dan dokumentasi. Tehnik analisis data yang digunakan adalah analisis data kualitatif deskriptif. Hasil penelitian ini menunjukkan bahwa: 1) Penerapan Model pembelajaran TANDUR pada pembelajaran IPS dikelas V SD Inpres Bontoloe terlaksana dengan baik Pembelajaran yang dilakukan sudah sesuai dengan langkah-langkah dalam model pembelajaran TANDUR, Peneliti menciptakan suasana pembelajaran yang menyenangkan, memberikan penguatan dan penghargaan kepada siswa, dan meyakinkan kemampuan siswa dalam memahami materi pembelajaran. 2) Hasil Belajar IPS Kelas V SD Inpres Bontoloe pada siklus I menunjukkan bahwa persentase siswa yang nilainya di atas KKM baru mencapai 67,86\%, sehingga masih belum dapat mencapai kriteria keberhasilan penelitian. Pada siklus II Persentase nilai siswa yang di atas KKM pada siklus II meningkat menjadi $100 \%$. Berdasarkan hasil penelitian dan pembahasan, dapat disimpulkan bahwa model pembelajaran TANDUR dapat meningkatkan hasil belajar IPS pada siswa Kelas V SD Inpres Bontoloe Kecamatan Bontolempangan Kabupaten Gowa.
\end{abstract}

Kata Kunci:Metode Penugasan atau Resitasi,Menulis,Karangan Eksposisi, Eksperimen 


\section{PENDAHULUAN}

Sesuai konteks pendidikan, $\begin{array}{r}\text { Ilmu } \\ \text { Pengetahuan Sosial (IPS) merupakan proses }\end{array}$
pembelajaran yang menghasilkan siswa yang
mampu berpikir kritis, analitis, dan kreatif.
Indikator keberhasilan IPS ditandai dengan
bertambahnya pengetahuan, keterampilan dan
perubahan perilaku siswa, serta tercapainya
ketuntasan belajar siswa sehingga siswa mampu
mengatasi masalahnya sendiri dan dapat menjalin
hubungan antarsesama manusia dan
lingkungannya.

Peningkatan hasil belajar sangat penting dalam penyelenggaraan pendidikan di sekolah dasar, khususnya pada pembelajaran Ilmu Pengetahuan Sosial IPS memiliki peranan dalam mengarahkan dan membimbing siswa pada nilainilai dan perilaku yang demokratis, memahami dirinya dalam kehidupan, dan memahami tanggung jawabnya sebagai bagian dari masyarakat global.

Penelitian dilaksanakan di SD Inpres Bontoloe adapun alasan Peneliti melaksanakan penelitian di SD Inpres Bontoloe yaitu selain karena lokasi yang mudah dijangkau dan ekonomis, pembelajaran guru di sekolah tersebut masih kurang dalam hal penggunaan model pembelajaran yang sesuai untuk peserta didik sehingga masih ada beberapa mata pelajaran yang yang belum mencapai Kriteria Ketuntasan Minimal (KKM ) yang telah ditetapkan disekolah tersebut terutama dalam mata pelajaran IPS yang memiliki KKM 75.

Berdasarkan observasi dan hasil wawancara peneliti pada hari Rabu 22 Januari 2020 di SD Inpres Bontoloe dengan Guru Kelas V SD Inpres Bontoloe Kecamatan Bontolempangan Kabupaten Gowa di ruangan Kelas V,terungkap bahwa hasil belajar siswa pada mata pelajaran IPS tergolong rendah dengan nilai rata-rata 68,71\% Hal ini disebabkan karena dalam proses pembelajaran yang dilakukan oleh guru di Kelas kurang efektif dan efisien, diantaranya dalam prose pembelajaran IPS guru masih menggunakan metode pembelajaran yang bersifat

konvensional dan kurang bervariasi, sehingga siswa kurang berminat dan cepat bosan dalam mengikuti proses pembelajaran IPS hal ini ditandai dengan siswa tidak fokus pada materi yang diajarkan kemudian kurangnya pengawasan dari guru sehingga siswa lebih banyak bermain dalam proses pembelajaran terutama siswa yang duduk dibangku paling belakang, kemudian guru kurang melibatkan siswa dalam proses pembelajaran sehingga sebagian besar siswa pasif dan pembelajaran hanya didominasi oleh siswa yang memiliki kemampuan tinggi saja.

Salah satu upaya yang dikembangkan oleh peneliti untuk menunjang peningkatan hasil belajar IPS siswa Kelas V SD Inpres Bontoloe Kecamatan Bontolempangan Kabupaten Gowa yaitu dengan menerapkan model pembelajaran TANDUR dalam pembelajaran ini dapat membuat siswa menyukai pelajaran sehingga dapat meningkatkan aktivitas belajar siswa karena siswa merasa tidak dipaksa dalam belajar.

TANDUR dapat diterapkan dalam berbagai pembelajaran, salah satunya adalah pembelajaran IPS. Ilmu Pengetahuan Sosial merupakan mata pelajaran yang sarat akan konsep dan konsepkonsep IPS tersebut perlu divisualisasikan agar menjadi konkret. Pembelajaran TANDUR dapat menjadi sarana untuk memungkinkan guru memberikan materi, menvisualisasikan dan menghubungkan dengan pengetahuan apa yang telah dimiliki siswa. Dengan demikian TANDUR dapat menfasilitasi siswa dalam meningkatkan hasil belajar IPS.

Tujuan Penelitian ini yaitu Untuk mengetahui bagaimana penerapan model pembelajaran TANDUR dan hasil belajar IPS siswa Kelas V SD Inpres Bontoloe Kecamatan Bontolempangan Kabupaten Gowa Setelah menerapkan Model Pembelajaran TANDUR.

\section{METODE PENELITIAN}

Penelitian ini merupakan penelitian tindakan kelas (Classroom Action Research). Secara sederhana, Arikunto (2015) mengemukakan bahwa "Penelitian Tindakan Kelas adalah penelitian tindakan (Action Research) yang dilakukan dengan tujuan memperbaiki mutu praktik pembelajaran di kelasnya

Penelitian ini dilaksanakan di SD Inpres Bontoloe Kecamatan Bontolempangan Kabupaten Gowa. pada semester Ganjil tahun pelajaran 2020/2021. Adapun subjek dalam penelitian ini adalah guru dan siswa kelas V SD Inpres Bontoloe Kecamatan Bontolempangan Kabupaten Gowa 
Jumlah siswa sebanyak 28 orang yang terdiri dari 12 orang laki-laki dan 16 orang perempuan.

Fokus pada penelitian ini yaitu Penerapan model pembelajaran TANDUR pada mata pelajaran IPS di Kelas V SD Inpres Bontoloe Kecamatan Bontolempngan hal ini dapat dilihat dari proses pembelajaran dengan menggunakan lembar observasi Aktivitas belajar siswa dan Guru.

Hasil belajar siswa setelah menggunakan model pembelajaran TANDUR pada mata pelajaran IPS di Kelas V SD Inpres Bontoloe.

Penelitian ini dilaksanakan melalui rancangan Penelitian Tindakan Kelas atau PTK yang terdiri dua atau tiga siklus, masing-masing siklus tingkatan keberhasilannya disesuaikan dengan kompetensi yang diharapkan dapat dikuasai siswa. Mekanisme penelitian ini didasarkan pada model Arikunto (2015) dengan tiap siklus mencakup 4 tahap yaitu perencanaan tindakan, pelaksanaan tindakan, observasi dan refleksi.

Instrumen merupakan alat yang digunakan untuk mengumpulkan data- data yang diperlukan dalam penelitian. Instrumen yang digunakan dalam penelitian ini adalah Lembar observasi, tes hasil belajar dan dokumentasi.

Teknik analisis data yang digunakan dalam penelitian ini adalah analisis data kualitatif deskriptif. Data yang diperoleh dari observasi mengajar guru dan belajar siswa yang dianalisis secara kualitatif. Sedangkan untuk hasil belajar IPS siswa kelas V SD Inpres Bontoloe Kecamatan Bontolempangan Kabupaten Gowa dengan menggunakan model pembelajaran TANDUR , berdasarkan tes hasil belajar siklus I dan II (hasil data kuantitatif) dianalisis secara deskriptif.

Indikator keberhasilan dalam penelitian ini dilihat dari dua segi, yaitu: Indikator proses dalam penelitian ini dilihat dari adanya peningkatan keaktifan, kerjasama dan rasa tanggungjawab siswa kelas V SD di SD Inpres Bontoloe Kecamatan Bontolempangan Kabupaten Gowa dalam proses pembelajaran melalui penerapan model pembelajaran TANDUR. Proses pembelajaran dikatakan berhasil apabila aktivitas mengajar guru dan belajar siswa berada pada kategori (C) dengan persentase $55 \%-69 \%$.
Indikator keberhasilan dalam penelitian ini adalah adanya peningkatan hasil belajar siswa kelas V SD Inpres Bontoloe pada pembelajaran IPS setelah menggunakan model pembelajaran TANDUR apabila terdapat $85 \%$ siswa yang memperoleh nilai minimal 75 maka kelas dianggap tuntas secara klasikal.

\section{HASIL PENELITIAN}

Dalam penelitian ini peneliti menggunakan jenis penelitian tindakan kelas. Peneliti menggunakan Model TANDUR Penelitian ini dilakukan dalam 2 siklus. Siklus 1 Pertemuan pertama dilaksanakan pada hari kamis tanggal 16 Juli 2020 dan pertemuan ke 2 dilaksanakan pada hari kamis tanggal 23 juli 2020 sedangkan siklus I Pertemuan 1 dilaksanakan pada hari pada hari rabu tanggal 05 Agustus 2020 dan pertemuan ke 2 dilaksanakan pada hari Rabu 12 Agustus 2020.

Adapun rancangan tindakan siklus I disusun sebagai berikut : Pertama Peneliti mengawali pembelajaran dengan menghadirkan permasalahan atau fakta yang dekat dengan kehidupan sehari-hari siswa untuk menumbuhkan motivasi siswa.

Kedua Siswa dibagi kedalam 4 kelompok secara Heterogen ketiga Berdasarkan permasalahan yang dimunculkan, siswa mengerjakan LKS dan saling berkompetisi secara sehat. keempat Pengetahuan yang telah diperoleh, didemonstrasikan oleh siswa dengan mempresentasikan hasil temuannya di depan kelas.

Kelima Peneliti meluruskan dan menguatkan konsep yang dipahami siswa dengan Tanya jawab. Keenam Memberikan Penghargaan.

1) Hasil observasi aktivitas guru siklus I

Pembelajaran tindakan siklus I diamati oleh guru kelas V SD Inpres Bontoloe Kecamatan Bontolempanagan Kabupaten Gowa. Adapun pelaksanaan tindakan siklus I yang terdiri dari pertemuan I dan II yang diamati untuk peneliti yang sesuai pada tabel 3.1 berikut.

Tabel 3.1 Data Hasil Observasi Aktivitas Mengajar Guru Siklus I

\begin{tabular}{|l|l|l|}
\hline \multirow{2}{*}{ Indikato } & \multicolumn{2}{|c|}{ Siklus I } \\
\cline { 2 - 3 } & Perte & Pertemuan \\
\hline
\end{tabular}




\begin{tabular}{|l|c|c|}
\hline $\mathbf{r}$ & $\begin{array}{c}\text { muan } \\
\mathbf{1}\end{array}$ & II \\
\hline $\begin{array}{l}\text { Sangat } \\
\text { Baik (5) }\end{array}$ & 1 & 2 \\
\hline Baik (4) & 2 & 4 \\
\hline $\begin{array}{l}\text { Cukup } \\
(3)\end{array}$ & 5 & 4 \\
\hline $\begin{array}{l}\text { Kurang } \\
(2)\end{array}$ & 2 & 0 \\
\hline $\begin{array}{l}\text { Sangat } \\
\text { Kurang } \\
(1)\end{array}$ & 0 & 0 \\
\hline $\begin{array}{l}\text { Persenta } \\
\text { se }\end{array}$ & $\begin{array}{l}\mathbf{6 4} \\
\text { Kategor }\end{array}$ & Cukup \\
i
\end{tabular}

Dari tabel 3.1 di atas dapat disimpulkan pada pelaksanaan tindakan siklus I menunjukkan bahwa proses pelaksanaan pembelajaran terlaksana dengan kategori cukup dan baik.

Tabel 3.2 Data Hasil Observasi Aktivitas Siswa Siklus I

\begin{tabular}{|l|l|l|}
\hline \multirow{2}{*}{ Indikator } & \multicolumn{2}{|l|}{ Siklus I } \\
\cline { 2 - 3 } & $\begin{array}{l}\text { Pertemua } \\
\text { n I }\end{array}$ & Pertemuan II \\
\hline Sangat Baik (5) & 0 & 1 \\
\hline $\begin{array}{l}\text { Baik } \\
(4)\end{array}$ & 1 & 2 \\
\hline $\begin{array}{l}\text { Cuku } \\
\text { (3) }\end{array}$ & 4 & 5 \\
\hline $\begin{array}{l}\text { Kurang (2) } \\
\text { Sangat Kurang } \\
(1)\end{array}$ & 5 & 2 \\
\hline Persentase & $\mathbf{5 2 \%}$ & $\mathbf{6 4 \%}$ \\
\hline Kategori & Kurang & Cukup \\
\hline
\end{tabular}

Dari tabel 3.2 dapat disimpulkan bahwa pada pelaksanaan tindakan siklus I menunjukkan bahwa proses pelaksanaan pembelajaran pada pertemuan pertama terlaksana dengan kategori kurang dan pada pertemuan kedua terlaksana dengan kategori cukup.

Tabel 3.3 Distribusi Frekuensi dan Persentase Hasil Belajar IPS Siklus I

\begin{tabular}{|c|c|c|c|}
\hline $\begin{array}{l}\mathbf{N} \\
\mathbf{0 .}\end{array}$ & Nilai & \begin{tabular}{|c|} 
Frekuens \\
i
\end{tabular} & $\begin{array}{c}\text { Persentase } \\
(\%)\end{array}$ \\
\hline 1 & 60 & 3 & $10,71 \%$ \\
\hline 2 & 65 & 2 & $7,14 \%$ \\
\hline 3 & 70 & 4 & $14,29 \%$ \\
\hline 4 & 75 & 5 & $17,86 \%$ \\
\hline 5 & 80 & $\begin{array}{l}1 \\
0\end{array}$ & $35,71 \%$ \\
\hline 6 & 85 & 2 & $7,14 \%$ \\
\hline 7 & 90 & 2 & $7,14 \%$ \\
\hline \multicolumn{2}{|c|}{ Total } & 28 & $100 \%$ \\
\hline
\end{tabular}

Berdasarkan tabel 3.3 di atas diketahui bahwa siswa kelas $\mathrm{V}$ yang sudah memenuhi kriteria ketuntasan minimal (KKM) yaitu $\geq 75$ terdapat 19 siswa $(67,86 \%)$. Hal tersebut dapat dilihat dari jumla frekuensi siswa yang mendapatkan nilai mulai 75 ke atas. Sedangkan yang belum mencapai kriteria ketuntasan minimal (KKM) yaitu $\geq 75$ terdapat 9 siswa $(32,14 \%)$ dapat dilihat dari jumlah frekuensi siswa yang mendapatkan nilai di bawah 75. Berikut kriteria pencapaian hasil belajar IPS di kelas V SD Inpres Bontoloe Kecamatan Bontolempangan Kabupaten Gowa.

Beberapa hal yang masih kurang dalam pembelajaran pada siklus 1, yaitu perlu diperbaiki pada siklus II dari pihak siswa yaitu: pertama Terdapat siswa yang kurang aktif dalam kegiatan kelompok, asyik bermain sendiri dan hanya mengandalkan ketua kelompok dalam mengerjakan tugas. Kedua Siswa juga masih malu untuk bertanya dan menyampaikan ide dan tanggapannya. Siswa kurang percaya diri dan tegas dalam menyampaikan pertanyaan.

Kendala-kendala tersebut harus segera ditangani agar upaya meningkatkan hasil belajar IPS degan model pembelajaran TANDUR pada siswa kelas V SD Inpres Bontoloe Kecamatan Bontolempangan Kabupaten Gowa dapat berjalan sesuai dengan rencana. Berdasarkan hasil observasi dan refleksi yang telah diperoleh, hasil belajar siswa dirasakan kurang maksimal karena belum sesuai dengan kriteria keberhasilan tindakan. Untuk perlu adanya rencana perbaikan yang akan dilaksanakan pada siklus selanjutnya, yaitu siklus ke-II.

Perencanaan pada siklus II hampir sama dengan perencanaan pada siklus I. Pelaksaan 
tindakan kelas siklus II dilakukan dengan memperhatikan hasil refleksi pada penelitian tindakan kelas siklus I. Kendala-kendala yang terdapat dalam pelaksanaan tindakan kelas siklus diupayakan untuk dapat di antisipasi.

Pelaksanaan siklus II tetap sama dengan pelaksanaan pada siklus sebelumnya yaitu observasi terhadap aktivitas proses belajar mengajar guru.

1) Data hasil observasi guru siklus II

Berdasarkan pengamatan observer, data hasil observasi aktivitas mengajar guru disajikan dalam tabel berikut.

Tabel 3.4 Data Hasil Observasi Aktivitas Mengajar Siklus II

\begin{tabular}{|l|c|c|}
\hline \multirow{2}{*}{ Indikator } & \multicolumn{2}{|c|}{ Siklus II } \\
\cline { 2 - 3 } & Pertemuan I & Pertemuan II \\
\hline Sangat Baik (5) & 5 & 9 \\
\hline Baik (4) & 4 & 4 \\
\hline Cukup (3) & 1 & 0 \\
\hline Kurang (2) & 0 & 0 \\
\hline $\begin{array}{l}\text { Sangat Kurang } \\
\text { (1) }\end{array}$ & 0 & 0 \\
\hline Persentase & $88 \%$ & $98 \%$ \\
\hline Kategori & Baik & Sangat Baik \\
\hline
\end{tabular}

Dari tabel di atas dapat disimpulkan bahwa pada pelaksanaan tindakan siklus II menunjukkan bahwa proses pembelajaran terlaksana dengan kategori sangat baik. Peneliti mengoptimalkan pembelajaran dengan fokus pada. pemahaman dengan selalu melakukan umpan balik dan membuat suasana belajar yang menarik dengan terus memberikan yel-yel dan pengutan kepada siswa.

\section{Tabel 3.5 Data Hasil Observasi Aktivitas Siswa} Siklus II

\begin{tabular}{|l|c|c|}
\hline \multirow{2}{*}{ Indikator } & \multicolumn{2}{|c|}{ Siklus II } \\
\cline { 2 - 3 } & Pertemuan I & Pertemuan II \\
\hline $\begin{array}{l}\text { Sangat Baik } \\
(5)\end{array}$ & 4 & 8 \\
\hline
\end{tabular}

\begin{tabular}{|l|c|c|}
\hline Baik (4) & 2 & 2 \\
\hline Cukup (3) & 4 & 0 \\
\hline Kurang (2) & 0 & 0 \\
\hline $\begin{array}{l}\text { Sangat Kurang } \\
(1)\end{array}$ & 0 & 0 \\
\hline Persentase & $\mathbf{8 0} \%$ & $96 \%$ \\
\hline Kategori & Baik & $\begin{array}{l}\text { Sangat } \\
\text { Baik }\end{array}$ \\
\hline
\end{tabular}

Dari tabel 4.4 dapat disimpulkan bahwa pada pelaksanaan tindakan siklus II dengan dua kali pertemuan menunjukkan proses pembelajaran terlaksana dengan sangat baik.

Hasil observasi menunjukkan bahwa pembelajaran dengan menggunakan model pembelajaran TANDUR sudah berjalan semakin baik, peneliti sudah bisa mengarahkan siswa untuk bisa kerja secara kelompok dan melakukan berbagai kegiatan pembelajaran.

Dari hasil tes didapat data yang berupa angka-angka mengenai jumlah skor yang diperoleh masing-masing siswa. Hasil analisis deskriptif kuantitatif menunjukkan nilai rata-rata kelas yang diperoleh keseluruhan siswa pada evaluasi siklus II dapat disajikan dalam tabel sebagai berikut.

\section{Ttabel 3.5 Distribusi Frekuensi dan Persentase} Hasil Belajar IPS Siklus II

\begin{tabular}{|c|c|c|c|}
\hline No. & Nilai & Frekuensi & Persentase (\%) \\
\hline 1. & 80 & 9 & $32,14 \%$ \\
\hline 2. & 90 & 9 & $32,14 \%$ \\
\hline 3. & 100 & 10 & $35,72 \%$ \\
\hline \multicolumn{2}{|c|}{ Total } & 28 & $100 \%$ \\
\hline
\end{tabular}

Berdasarkan tabel 3.5 di atas dapat diketahui bahwa sebagian besar siswa kelas $\mathrm{V}$ sudah memenuhi kriteria ketuntasan minimal (KKM) yaitu $\geq 75$. Berikut kriteria pencapaian hasil belajar IPS pada siklus II.

\section{PEMBAHASAN}

Berdasarkan hasil tes yang dilakukan oleh peneliti pada siklus I, diperoleh data hasil belajar siswa yang memiliki skor $<75$ atau memiliki hasil 
belajar rendah sebanyak 9 siswa $(32,14 \%)$, skor 60 74 atau memiliki hasil belajar tinggi sebanyak 19 siswa $(67,86 \%)$ dan skor 75-90. Berdasarkan data tersebut maka dapat dikatakan hasil belajar IPS siswa kelas V SD Inpres Bontoloe Kecamatan Bontolempangan Kabupaten Gowa, cukup rendah karena tidak mencapai nilai Kriteria Ketuntasan Minimum (KKM) yaitu 75. Kurangnya perhatian siswa pada saat kegiatan pembelajaran sehingga banyak yang bermain dan siswa bosan dengan gaya mengajar peneliti menjadi masalah rendahnya hasil belajar siswa oleh karena itu, perlu adanya upaya atau tindakan perbaikan yang harus segera dilakukan untuk meningkatkan hasil belajar yang rendah tersebut.

Brophy (2013:8) menjelaskan bahwa strategi yang digunakan untuk memberikan rangsangan agar siswa termotivasi dalam kegiatan pembelajaran adalah dengan dengan menciptakan lingkungan pembelajaran yang kondusif, perencanaan pembelajaran yang penuh variasi, memberi kesempatan siswa untuk berperan aktif dalam kegiatan pembelajaran dan adanya kegiatan yang menarik dalam pembelajaran. Tindakan yang dipilih oleh peneliti yaitu dengan menerapkan model pembelajaran TANDUR pada mata pelajaran IPS.

Hasil penelitian terhadap hasil belajar siswa setelah diberikan pada siklus I menunjukkan adanya peningkatan bila dibandingkan dengan siklus II. Hal ini ditunjukkan dengan persentase siswa pada pertemuan pertama adalah 52\% termasuk kategori kurang dan pertemuan kedua adalah 64\% masuk dalam kategori cukup pada siklus I. Pada siklus II, persentase siswa pada pertemuan pertama adalah $80 \%$ termasuk kategori baik dan pertemuan kedua adalah $96 \%$ masuk dalam kategori sangat baik.

\section{SIMPULAN}

Berdasarkan Hasil Observasi secara keseluruhan pelaksanaan pembelajaran IPS dengan model pembelajaran TANDUR sudah berjalan dengan lancar. Pembelajaran yang dilakukan sudah sesuai dengan langkah-langkah dalam model pembelajaran TANDUR dan Hasil penelitian siklus I menunjukkan bahwa persentase siswa yang nilainya di atas KKM baru mencapai 67,86\%, sehingga masih belum dapat mencapai kriteria keberhasilan penelitian. Pada siklus II Persentase nilai siswa yang di atas KKM pada siklus II meningkat menjadi 100\%.

Peningkatan hasil belajar siswa dalam pembelajaran IPS dengan menggunakan Model Pembelajaran TANDUR yang di kembangkan melalui penelitian tindakan kelas (PTK) ini diharapkan memberikan kontribusi sebagai berikut:

Bagi Siswa diharapkan dengan hasilnya penelitian ini, siswa diharapkan dapat lebih berani dan percaya diri dalam mengajukan pertanyaan dan menjawab pertanyaan yang sesuai dengan materi pembelajaran, Kerja sama dan menghargai pendapat siswa lain dalam kerja kelompok/diskusi kelompok perlu dikembangkan dalam pembelajaran supaya mendapatkan hasil yang baik.

Bagi Guru, diharapkan dapat menjadi pedoman untuk kegiatan pembelajaran berikutnya, memiliki keterampilan dalam mengajar serta dalam memodifikasi berbagai strategi dalam model pembelajaran TANDUR.

Calon peneliti yang akan melakukan penelitian dalam bidang kependidikan agar dapat meneliti lebih lanjut tentang model- model pembelajaran yang lebih efektif dan efisien.

\section{DAFTAR PUSTAKA}

[1] Abdurrahman, M.2012. Anak Berkesulitan Belajar Teori Diagnostik, dan Remidiasinya. Jakarta: Rineka Cipta.

[2] Arifin, Dedy. 2017. Pengertian Model Pembelajaran Tandur. (online) http://dedyarifin.blogspot.com/2017/03/model -pembelajaran-tandur.html. Diakses 11 Mei $\underline{2020 .}$

[3] Aunurahman. 2009. Belajar dan Pembelajaran. Pontiank: Alfabeta.

[4] Arikunto, S. 2015. Penelitian Tindakan Kelas. Jakarta: Bumi Aksara 
[5] De Porter, B. 2003. Quantum Learning Membiasakan Belajar Nyaman dan Menyenangkan. Bandung: Kaifa.

[6] Daryanto.2014. Pendekatan Pembelajaran Saintifik Kurikulum 2013. Yogyakarta: Gava Media.

[7] Gunawan, R. 2011. Pendidikan IPS Filosofi, Konsep dan Aplikasi. Jakarta: Alfabeta.

[8] Ihwani, 2014. Langkah - langkah Model Pembelajaran TANDUR, (Online), (http://Ihwanifisika.blogspot.com/2014/02/vbehaviorurldefaultvmlo.html?m=1, Diakses 13 April 2020.

[9] Kunandar. 2013. Penilaian Autentik ( Penilaian Hasil Belajar Peserta Didik Berdasarkan Kurikulum 2013) Suatu Pendekatan Praktis. Jakarta: PT Grafindo Persada.

[10] Sardjiyo, Didih., \& Ischak. 2009. Pendidikan IPS di SD. Jakarta: Universitas Terbuka.

[11] Susanto, A.2013. Teori Belajar dan Pembelajaran di SD. Jakarta: Kencana Prenada Media Group.

[12] Sudjana, N. 2008. Penilaian Hasil Proses Belajar Mengajar. Bandung: Remaja Rosdakarya

[13] Shoimin, Aris. 2014. Model Pembelajaran Inovatif dalam Kurikulum 2013. Yogyakarta: AR-ruz media.

[14] Solihatin, Etin dan Raharjo. 2007. Peningkatan Hasil Belajar. Jakarta: Bumi aksara.

[15] Slameto. 2010. Belajar dan Faktor-Faktor yang Mempengaruhinya. Jakarta: Rineka Cipta.

[16] Syah, Muibbin. 2008. Psikologi Pendidikan dengan Pendekatan Baru. Bandung: Remaja Rosdakarya.

[17] Trianto. 2013. Model Pembelajaran Terpadu Konsep Strategis, dan Implementasinya dalam KTSP. Jakarta: PT Bumi Aksara.

[18] Sa'ud, Udin Saefuddin. 2008. Inovasi Pendidikan. Bandung: Alfabeta.

[19] Undang-Undang RI Nomor 20 Tahun 2003 Bagian Penjelasan Tentang Sistem Pendidikan Nasional.2003.Jakarta: Kemendikbud.

[20] Vistanisti. 2013. Pengertian Metode. (Online),http://Vistanisti-meblog.
Blogspot.com/2013/05/pengertian -metode.html, Diakses 14 April 2020 